\title{
Interactive effect of calcium and magnesium on the growth and yield of tomato (Lycopersicon esculentum L.)
}

\author{
Mohammad Ilyas ${ }^{1 *}$, Manzoor Ahmad ${ }^{3}$, Zahid Hussain ${ }^{2}$, Ammara Saeed $^{1}$, \\ Farzana Begum ${ }^{1}$, Luqman ${ }^{2}$, Kamran Shah ${ }^{1}$, Mohammad Imtiaz Khan ${ }^{4}$ \\ and Sumayya Shah ${ }^{1}$ \\ 1. Department of Horticulture' The University of Agriculture, Peshawar-Pakistan \\ 2. Department of Weed Science, The University of Agriculture, Peshawar-Pakistan \\ 3. Department of Agriculture Bacha Khan University Charsadda- Pakistan \\ 4. Fodder Livestock Research and Development Department Peshawar- Pakistan \\ *Corresponding author's email: ilyas_swati88@yahoo.com \\ Citation \\ Mohammad Ilyas, Manzoor Ahmad, Zahid Hussain, Ammara Saeed, Farzana Begum, Luqman, Kamran Shah, \\ Mohammad Imtiaz Khan and Sumayya Shah. Interactive effect of calcium and magnesium on the growth and yield \\ of tomato (Lycopersicon esculentum L.). Pure and Applied Biology. Vol. 5, Issue 4, pp876-882. \\ http://dx.doi.org/10.19045/bspab.2016.50110
}

Received: 14/06/2016 Revised: 08/08/2016

Accepted: $15 / 08 / 2016$

Online First: 17/08/2016

\section{Abstract}

Deficiency of calcium and magnesium has a negative impact on plant growth and yield. In this study quantitative parameters of growth and yield in Peshawar were studied by spraying different levels of calcium and magnesium on foliage of tomato (Lycopersicum esculentum L.). Calcium chloride source was used as calcium at $\mathrm{Ca}_{1}(0 \%), \mathrm{Ca}_{2}(0.15 \%), \mathrm{Ca}_{3}(0.30 \%)$ and $\mathrm{Ca}_{4}(0.45 \%)$ and magnesium sulphate source was used as magnesium at $\mathrm{Mg}_{1}(0 \%), \mathrm{Mg}_{2}(0.04 \%), \mathrm{Mg}_{3}(0.08 \%)$ and $\mathrm{Mg}_{4}(0.12 \%)$ with 15 days interval after transplantation for a period of three months. The maximum plant height $(75.78 \mathrm{~cm})$, number of branches plant ${ }^{-1}(8.02)$, number of flowers cluster plant $^{-1}$ (22.40), number of fruits plant ${ }^{-1}$ (33.04) and total yield (ton ha ${ }^{-1}$ ) (23.07) was observed in plants with $0.30 \%$ calcium application. Similarly, maximum plant height $(72.98 \mathrm{~cm})$, number of branches plant ${ }^{-1}$ (7.94), number of flowers cluster plant ${ }^{-1}(21.57)$, number of fruits plant ${ }^{-1}(31.01)$ and total yield (ton ha ${ }^{-1}$ ) (21.54) was observed in plants with $0.08 \%$ magnesium application. This study suggests that calcium and magnesium at the rate of $0.30 \%$ and $0.08 \%$ with 15 days interval after transplantation significantly increase the yield and growth under the agro climatic and soil condition of Peshawar valley.

Keywords: Calcium; Magnesium; Tomato

\section{Introduction}

Tomato scientifically known as Lycopersicon esculentum ranks first in solanaceae family. It is a famous horticulture produce, grown up all over the world. Tomato in relation to human health is the most demanding produce required in every day food in most countries. Tomato is chief source of natural resources, vitamins as well as antioxidants. Tomatoes grown on all types of soil but for the best results with respect to yield need loamy soil, welldrained and the soil which have more natural substance and mostly the availability 
of nutrients [1]. It originated in Western South America which is 300 latitude from the equator. The features of this family are determinate and indeterminate where the three nodes generate within each inflorescence and soon after initiate less than three nodes on stem and thus finish the inflorescence [2]. Tomatoes crops give more yield by applying the proper amount essential fertilizer at proper occasion that is require for the growth and best yield of tomatoes. Commonly the most basic essential fertilizers i-e. nitrogen, phosphorus and potassium should be applied at the rate of 75-60-60 kg ha-1. The fertilizer should be applied to land in three different stages. Firstly during land treatment, secondly after transplanting and thirdly after the initial picking of fruit. Half amount of fertilizer (nitrogen, phosphorus and potassium) as well as complete 30 tons per hactare farm yard manure will be provide to the land during the land treatment and other half amount should be applied after transplanting and then after the initial picking [3]. Other than field crop, it is grown in almost home gardens. It is also grown other than its normal season in green house as forcing vegetables. Tomato is important source of vitamins $\mathrm{A}$ and $\mathrm{C}$ as well as minerals and phosphorus used to manufacture ketchup etc [4]. In Pakistan two crops of tomato are produced annually. One as a spring crop for which the seed is sown in november and the seedling are ready for transplantation in february. This crop is ready from may and continuous up to august. The second crop is seeded in june and seedlings are transplanted in august. The crop is ready to yield in the month of november continuing till march [5]. Tomato is a warm season crop and requires a relatively long season to produce fruit. It is tender and will not stand hard freeze. In regions having less than three and half month frost-free period, it is not like to be profitable. High humidity with high temperature favors the development of foliar diseases. On the other hand, hot drying winds often results in the dropping of blossom [2]. Tomato producers require more yield and good quality fruit with respect to size, shape. Such type of quality and yield are obtained if certain techniques are follow i-e. proper selection of variety which are resistance to any stress and give more yield, proper irrigation requirement, terminating the disease causing organism, status of the soil as well as climatic requirement etc. Many researchers and horticulturist observed that different nutrients and the above discuss technique play a key role in the development, plant growth as well as more yield [6]. The main component of the chlorophyll is the magnesium. Magnesium also helps in speed up the enzyme activity and play important role in energy transport reactions. Calcium is the main component of cell walls and it play a key role in sustaining cell wall consistency and membrane permeability. Calcium also improves to increase the growth and development of the plant as well as pollen germination. Calcium also increase the speed of enzyme to increase mitosis, cell splitting as well as to increase the size of the cell and produce more fruit of good quality to increase the yield of tomato crops [7]. Calcium has been recognized as relatively immobile element in plants. Once it reaches the leaves it becomes highly immobile and is not recycled even under calcium stress situation. Therefore, a continuous supply is needed for tissues, such as root tips and leaves [8]. Commonly the absence of one element is not only due to exact fertilizer arrangement but it occurs due to the effect of one element on the availability of other element that is not easy to avoid. Such type of effect occurs between calcium, magnesium and potassium. Due to magnesium deficiency in the plant photosynthetic pigments like magnesium protoporphyrin declines and 
transfers to other parts and thus magnesium deficiency occurs. Also due to deficiency of potassium the fruit production is decrease and the quality of fruit also affected [9]. Due to calcium deficiencies the growth of meristematic tissue affected and thus causes small leaves production, lower yield and mostly cases cause the disease of blossom end rot on juvenile leaves. Due to less magnesium concentration than optimum level leaf chlorosis occur in leaves and thus decrease fruit yield. Magnesium concentration up to optimum level enhanced fruit inflexibility, leaf size as well as root growth and thus increased the yield of tomato crops [10]. Calcium is essential for cell wall, cell growth, cell division, nitrogen assimilation and acting as a cofactor for some enzymes. Its functions in plants are follows. Promotes early roots formation and growth, influences intake of other plants food, neutralizes poisons produced in plant, encourage seed and grain production, increase calcium content of food and feed crops, participates in metabolic processes of other nutrients uptake, promotes proper plant cell elongation, strengthen cell wall, essential part of plant cell wall. it forms calcium pectate compounds which give stability to the cell walls and bind cell together, participates in enzymatic and hormonal processes, helps in protecting the plant against heat stress, improves stomata function and participates in induction of heat shock proteins, helps in protecting the plant against diseases numerous fungi and bacteria secret enzymes which impair plant cell wall, stronger cell walls, induced by calcium, can avoid the invasion, affects fruit quality and important role in the regulation of stomata. To overcome the calcium deficiency it should be added to the soil as limestone before planting or sprayed on foliage. Calcium loss from the soil occurs in many ways i-e. Erosion, crop removal, through leaching, when applied to the soil directly [4]. Optimum quantity of calcium, magnesium in solution not only increases the yield of tomato but also better the quality of tomato. Due to the deficiencies of these nutrients sometime disease and disorder occurs i-e blotchy ripening (BR), cat facing $(\mathrm{CF})$, fruit cracking (FC), and blossom-end rot (BER). In the case of BER, which can cause severe profitable sufferers occur, numerous researches and horticulturists observed that such type of abnormalities and disease occur due to calcium deficiency [11].

\section{Material and methods}

An experiment "Interactive Effect of calcium and magnesium on the growth and yield of tomato" was carried out at Newly Developmental Farm, Horticulture section, The University of Agriculture Peshawar. The details of the experiment are given below. The experiment was laid out in (RCBD) with two factorial i.e. Calcium and magnesium. Experiment was replicated three times. Row to row distance was kept as $100 \mathrm{~cm}$ while plant to plant was $30 \mathrm{~cm}$. Variety under the field trial was Roma. The seeds were sown in March. Land was ploughed well and soil sample was taken for chemical analysis. Seedlings were transplanted in April. Raised beds were prepared at a distance of 1 meter. Seedling of uniform size was transplanted to the raised beds. Nitrogen was given to the treatment at the rate of $150 \mathrm{~kg}$ in the form of Urea, similarly $100 \mathrm{~kg} \mathrm{P}_{2} \mathrm{O}_{3}$ in the form of triple super phosphate and $60 \mathrm{~kg} \mathrm{~K}_{2} \mathrm{O}$ in the form of potassium sulphate to the treatment. Different practices like irrigation, control of pathogen, weed control was done at proper time. The calcium and magnesium was applied as a foliar spray to the tomato crop with a regular interval of 15 days for 3 months after transplantation. There were a total of 16-treatments replicated three times. 
Table. 1 Treatments details

\begin{tabular}{|ll|lc|}
\hline \multicolumn{2}{|l|}{ Factor A } & Calcium levels & \multicolumn{2}{|l|}{ Factor B Magnesium levels } \\
\hline $\mathrm{Ca}_{1}$ & Control & $\mathrm{Mg}_{1}$ & control \\
\hline $\mathrm{Ca}_{2}$ & $0.15 \%$ & $\mathrm{Mg}_{2}$ & $0.04 \%$ \\
\hline $\mathrm{Ca}_{3}$ & $0.30 \%$ & $\mathrm{Mg}_{3}$ & $0.08 \%$ \\
\hline $\mathrm{Ca}_{4}$ & $0.45 \%$ & $\mathrm{Mg}_{4}$ & $0.12 \%$ \\
\hline
\end{tabular}

\section{Result and discussion Plant height (cm)}

The statistical analysis shows that foliar application of calcium and magnesium and there interaction have significant effect on plant height. Maximum plant height (75.73 $\mathrm{cm})$ was observed with $0.3 \%$ calcium application while it was minimum (64.72 $\mathrm{cm})$ in control treatment. Regarding magnesium, maximum plant height (72.98 $\mathrm{cm}$ ) was observed with $0.08 \%$ magnesium application while the minimum plant height $(66.82 \mathrm{~cm})$ was observed in control fertilizer condition. In case of interaction maximum plant height $(77.66 \mathrm{~cm})$ was observed with the foliar application of calcium and magnesium at the rate of $0.30 \%$ and $0.08 \%$ correspondingly. Calcium is an important nutrient that performs important role in the cell walls and cell membrane structure, fruit growth, development as well as general fruit quality. It enhances resistance to bacterial and viral diseases. These results are similar to the [12] who stated that the plant height of tomato plants increased with the application of calcium chloride at the rate of $0.3 \%$. Magnesium play a key role in the growth and improvement of new cells and thus with the application of magnesium more growth is occur. These results are close to that of [13] who stated that plant height increased with the foliar application of magnesium.

\section{Number of branches plant ${ }^{-1}$}

It is evident from the statistical analysis that foliar application of calcium and magnesium and their interaction having significant effect on number of branches plant ${ }^{-1}$. Maximum numbers of branches plant $^{-1}$ (8.02) was observed with $0.3 \%$ calcium application while the minimum number of branches plant $^{-1}$ (6.13) was observed in control fertilizer application. Magnesium application@0.08\% resulted the maximum number of branches plant ${ }^{-1}$ (7.95) while the minimum number of branches plant ${ }^{-1}$ (6.30) was observed in control fertilizer condition. Regarding interaction maximum number of branches plant ${ }^{-1}$ (8.66) was observed with the foliar application of calcium and magnesium at the rate of $0.30 \%$ and $0.08 \%$ respectively. The increased in the number of branches is similar to that of plant height affected with the foliar application of calcium. These results are nearly close to that of [14] who stated that number of branches increased with the foliar application of calcium and magnesium. With the application of magnesium the growth of new cells take place in the meristem of the plants and thus it increased plant height and due to more plant height more branches production occur [13].

\section{Number of flower cluster plant ${ }^{-1}$}

Foliar application and their interaction having significant effect on number of flowers cluster plant ${ }^{-1}$ (Table -1). Maximum number of flowers cluster plant ${ }^{-1}$ (22.45) was observed in $0.30 \%$ calcium application while minimum number of flowers cluster plant $^{-1}$ (15.52) was observed in control fertilizer condition. As for as magnesium, the number of flowers cluster plant $^{-1}$ increased from 16.56 to 21.58 with the foliar application of $0.08 \%$ magnesium and (20.62) with magnesium application of $0.12 \%$. Maximum number of flowers cluster plant $^{-1}$ (26.10) was observed in case of interaction with foliar application of calcium and magnesium at the rate of $0.30 \%$ and 
$0.08 \%$ correspondingly. As compared to control the number of flower cluster per plant increased with the foliar application of calcium and magnesium. Application of calcium uptake the phosphorus and due phosphorus uptake the number of flower cluster plant ${ }^{-1}$ increased [15]. [16] stated that due to magnesium deficiency the interveinal chlorosis occur in the older leaves from the margins to the fine vein and finally the whole leaf become pale yellow and thus flower abscission occur and fruit loose firmness.

\section{Number of fruits plant $\mathbf{t}^{-1}$}

Maximum number of fruits plant ${ }^{-1}$ (33.04) was observed in $0.3 \%$ calcium application while the minimum number of fruits plant $^{-1}$ (23.22) was observed in control fertilizer condition. The data observed from statistical analysis shows that the maximum number fruits plant ${ }^{-1}$ (31.01) was observed in $0.08 \%$ magnesium application while the minimum number of fruits plant ${ }^{-1}$ (22.99) was observed in control fertilizer condition. Regarding interaction maximum number of fruits plant $^{-1}$ (38.13) was observed in with the foliar application of calcium and magnesium at the rate of $0.30 \%$ and $0.08 \%$ correspondingly. The result were similar to [18], who stated that the number of fruit plant $^{-1}$ increases with application the calcium fertilizer. Due to the calcium insufficiency a known disease blossom end rot occur in tomato. Such disease occurs due to less availability of calcium to the plants. These finding was similar to [19], who stated that magnesium is the main constituent of organic acids, chlorophyll and pectin. The number of fruits per plants is significantly improved with the application of magnesium fertilizer at the rate of $0.08 \%$. With the in Calcium application increased the number of fruits per plant .The number of fruit per plants has directly related to number of flower and cluster per plant. More number of fruits per plant obtained when the number of flower and cluster per plant. The decease and increased occur may also due to genetic effect. My results findings are close to that of [20] stated that number of fruits improved by applying calcium.

Total yield (ton ha-1)

It is evident from the statistical analysis that calcium and magnesium foliar application and their interaction have significant effect on total yield ton $\mathrm{ha}^{-1}$. Maximum total yield ton $\mathrm{ha}^{-1}$ (23.07) was observed in $0.30 \%$ calcium application while the minimum total yield ton $\mathrm{ha}^{-1}$ (17.42) was observed in control fertilizer condition. Maximum total yield ton $\mathrm{ha}^{-1}$ (21.54) was observed in $0.08 \%$ magnesium application while the minimum total yield ton $\mathrm{ha}^{-1}$ (18.86) was observed in control fertilizer condition. The interaction effect indicates that the maximum total yield ton $\mathrm{ha}^{-1}$ (24.41) was observed in case of interaction with the foliar application of calcium and magnesium at the rate of $0.30 \%$ and $0.08 \%$ correspondingly. Calcium concentration up to optimum level increased tomato production and decrease the occurrence of blossom end rot. So it is suggested that calcium concentration up to optimum level at the rate of $0.3 \%$ are require for the best yield of tomato. Less magnesium concentration in the leaves chlorosis occur and thus decrease production. Magnesium concentration up to optimum enhanced leaf size, root growth, as well as fruit firmness and thus increased the yield of tomato crops [10]. To obtained the more yield of tomato the application of fertilizers is required at proper time and proper occasion. The minor fertilizers like calcium, magnesium, copper, boron, zinc should also be applied for the high yield as well as the best quality of tomatoes [2]. 
Table 1. Plant height (cm), Number of branches plant ${ }^{-1}$, Number of flowers cluster plant ${ }^{-1}$, Number of fruits plant ${ }^{-1}$ and Total yield $\left(\mathrm{t} \mathrm{ha}^{-1}\right)$ of tomato plant as affected by foliar application of calcium and magnesium

\begin{tabular}{|l|l|l|l|l|l|}
\hline $\begin{array}{l}\text { Treatments } \\
\text { (Calcium } \\
\text { Levels) }\end{array}$ & $\begin{array}{l}\text { Plant height } \\
(\mathbf{c m})\end{array}$ & $\begin{array}{l}\text { Number of } \\
\text { branches }_{\text {plant }}^{-1}\end{array}$ & $\begin{array}{l}\text { Number of } \\
\text { flowers } \\
\text { plant }^{-1}\end{array}$ & $\begin{array}{l}\text { Number of } \\
\text { cluster } \\
\text { fruits plant }\end{array}$ & $\begin{array}{l}\text { Total yield } \\
\left.\text { (ton ha }^{-1}\right)\end{array}$ \\
\hline Ca1 & $64.45 \mathrm{~d}$ & $6.13 \mathrm{~d}$ & $16.13 \mathrm{~d}$ & $23.23 \mathrm{c}$ & $17.42 \mathrm{~d}$ \\
\hline Ca2 & $70.12 \mathrm{c}$ & $6.90 \mathrm{~b}$ & $18.40 \mathrm{c}$ & $25.55 \mathrm{c}$ & $19.21 \mathrm{c}$ \\
\hline Ca3 & $75.78 \mathrm{a}$ & $8.02 \mathrm{a}$ & $22.40 \mathrm{a}$ & $33.04 \mathrm{a}$ & $23.07 \mathrm{a}$ \\
\hline Ca4 & $71.70 \mathrm{~b}$ & $7.15 \mathrm{~b}$ & $20.25 \mathrm{~b}$ & $27.50 \mathrm{~b}$ & $21.28 \mathrm{~b}$ \\
\hline LSD & 0.48 & 0.33 & 0.80 & 0.11 & 0.11 \\
\hline Magnesium Levels & $66.82 \mathrm{~d}$ & $6.30 \mathrm{~d}$ & $16.56 \mathrm{~d}$ & $22.99 \mathrm{~d}$ & $18.86 \mathrm{~d}$ \\
\hline Mg1 & $70.32 \mathrm{~b}$ & $6.70 \mathrm{c}$ & $17.90 \mathrm{c}$ & $26.58 \mathrm{c}$ & $19.74 \mathrm{c}$ \\
\hline Mg2 & $72.98 \mathrm{a}$ & $7.94 \mathrm{a}$ & $21.57 \mathrm{a}$ & $31.01 \mathrm{a}$ & $21.54 \mathrm{a}$ \\
\hline Mg3 & $72.30 \mathrm{~b}$ & $7.30 \mathrm{~b}$ & $20.72 \mathrm{~b}$ & $28.74 \mathrm{~b}$ & $20.68 \mathrm{~b}$ \\
\hline Mg4 & 0.48 & 0.33 & 0.80 & 0.11 & 0.11 \\
\hline LSD & $*$ & $*$ & $*$ & \\
\hline Interaction & $*$ & $*$ & $*$ & \\
\hline Significance & $*$ &
\end{tabular}

\section{Conclusion and recommendations}

It is observed from the research experiment that the application of calcium at the rate of $0.30 \%$ and magnesium at the rate of $0.08 \%$ showed maximum growth and yield in tomato and is recommended for the maximum growth and yield in tomato under the agro climatic condition of Peshawar valley.

\section{Authors' contributions}

Conceived and designed the experiments: $M$ Ahmad, Performed the experiments: $M$ Ilyas, Analyzed the data: Z Hussain, Contributed reagents/ materials/ analysis, tools: MI Khan \& S Shah, Wrote the paper: A Saeed, F Begum, Luqman \& K Shah.

\section{References}

1. Grierson D \& Kader AA (1986). Fruit ripening and quality. The tomato crop. Chapman and Hall, London. Pp: 240280.

2. Jones JB (1999). Tomato plant culture: in the field, green house and home garden.CRS Press, LLC Florida, pp: 1153.

3. Thompson HC \& Kelly WC (1985). Vegetable crops. Fifth edition. Mcgraw- hill book company, Inc. New York Toronto London. P 676.

4. Hundson TH, Kofranek AM, Rubatzky VE \& Flocker WJ (1988). Plant Sci, pp: 674.

5. Shahid R (1999). The effect of calcium in prolonging the shelf life of tomato. Thesis submitted to the department Of Horticulture, NWFP Agriculture University. Peshawar, pp: 36.

6. Adams P (1986). The tomato crop: A scientific basis for improvement. Mineral Nutrition. New Yogmann, Wrk Horticulture Research International, Wellsbourne, U.K.17-31.

7. Cockshull KE, Gray D, Seymour GB \& Thomas B (1998). Improving tomato fruit quality by cultivation. In: Genetic environmental manipulation of horticultural crops. CABI publishing, Hort. Res. Inter. Wellsbourne, U.K.1731.

8. Poorvaiah BW \& Leopold AC (1976). Effects of inorganic salts on the tissue permeability. Plant Physiology, 58:182185.

9. Sonneveld C \& Voogt W (1991). Effect of Calcium stress on blossom end rot 
and $\mathrm{Mg}$ deficiency in rock wool grown tomato. Acta Hort 294: 81-88.

10. Hao X \& Papadopoulos AP (2004). Effects of calcium and magnesium on growth, fruit yield and quality in greenhouse tomato crop grown on rockwool. Canadian Journal Plant Science 83: 903-912.

11. Bradfield EG \& Guttridge CD (1984). Effect of night time humidity and nutrition solution concentration on the calcium content of tomato fruit. J Horti Sci 22:207-212.

12. Rab A \& Haq I (2009). Foliar application of calcium chloride and borax influences plant growth, yield and quality of tomato. J.Plant. Sci. 42:695-701.

13. Chapagain R \& Menzies E (2003). Influence of calcium and magnesium on the growth and yield of tomato. J.Vege. Sci., 17(3):132-139.

14. Reisenauer KK \& Synder RG (1993). Response of tomato to calcium application in Chotanagpur. J.Veg.Res. 7(3): 152-154.
15. Dorais M \& Marcelis (2003). Tomato crop. In " Vegetable growing” Pub.co. Agrobios. Australia. Pp:63-66.

16. Bergmann W (1992). Nutritional disorders of plants. Development, visual and analytical daigonsis. J. Vege. Sci., 22(4): 332-339.

18. Taylor MD \& Locascio SJ (2004). Blossom end rot: a calcium deficiency. J. Plant Nutrition, 27(1):123:139.

19. Upendra M, Sainjul E, Ramdane D \& Ozbun JL (2002). The effect of mineral nutrition of tomato. Plant Physiology, 56:123-125.

20. Haung JS (2003). Effect of boron, calcium and surface moisture on shoulder check, a quality defect in fresh market tomato. J. Ameri. Soci.Horti. Sci. 129(4):599607.

21.Usten NH, Yokas AL \& Saygili H (2006). Influence of potassium and calcium level on severity of tomato pith necrosis and yield of greenhouse tomatoes. ISHS Acta Horticulture, 808: $345-350$ 